\title{
IMPLEMENTASI KEBIJAKAN PEMBENTUKAN KARAKTER PEDULI LINGKUNGAN
}

\section{IMPLEMENTATION OF THE POLICY FOR ESTABLISHMENT OF ENVIRONMENTAL CARE CHARACTERS}

\author{
LN Farida1a dan Karwadi ${ }^{1}$ \\ 1 Program Pascasarjana, Program Studi Pendidikan Agama Islam, Fakultas Ilmu Tarbiyah dan \\ Keguruan, Universitas Islam Negeri Sunan Kalijaga Yogyakarta, Jalan Laksda Adisucipto, Caturtunggal, \\ Kecamatan Depok, Kabupaten Sleman, Daerah Istimewa Yogyakarta 55281 \\ a Korespondensi: Lilik Nur Farida, Email: liliknurf@gmail.com \\ (Diterima: 12-01-2019; Ditelaah: 28-01-2019; Disetujui: 10-03-2019)
}

\begin{abstract}
The study aims to know and describe about policy, implementation stage and the successful implementation of the policy for establishment of environmental care characters in SMP N 1 Ngemplak Sleman Yogyakarta. This research is a qualitative research with descriptive analysis method. Data were collected by some in-depth interviews, observation, and documentation. Data were analyzed by Miles \& Huberman style of data analyze with data reduction activities, data presentation, conclucions, and validity test of data used source triangulation techniques and triangulation techniques. Based on the results of the research, SMP N 1 Ngemplak Sleman Yogyakarta applied a policy for establishment of environmental care characters that refers to the school's vision and mission. The vision and mission are a follow up of government policies which related to establishment of national characters. The implementation stage of the policy includes socialization, implementation, and evaluation. The implementation of this policy shows its success with the majority of school residents get used to keep the environmental cleanliness and has a commitment to run the environmental care activities. The values of the environmental care characters are considered according the Ministry of National Education program, this is desired by Islam which implied in Allah SWT's word at Q.S. Ar-Ruum verse 41 and Q.S. Al-Qashash verse 77.
\end{abstract}

Keywords: environmental care characters, implementation, policy.

\begin{abstract}
ABSTRAK
Penelitian ini memiliki tujuan mengetahui dan mendeskripsikan terkait kebijakan, tahap implementasi dan keberhasilan implementasi kebijakan pembentukan karakter peduli lingkungan di SMP N 1 Ngemplak Sleman Yogyakarta. Penelitian ini merupakan penelitian kualitatif dengan metode deskriptif analisis. Teknik pengumpulan data yang digunakan meliputi wawancara mendalam, observasi, dan dokumentasi. Analisis data menggunakan analisis data Miles \& Huberman dengan aktivitas reduksi data, penyajian data, dan kesimpulan, serta dilakukan uji keabsahan data menggunakan teknik triangulasi sumber dan triangulasi teknik. Berdasarkan hasil penelitian yang telah dilakukan, SMP N 1 Ngemplak Sleman Yogyakarta menerapkan kebijakan pembentukan karakter peduli lingkungan yang mengacu kepada visi dan misi sekolah. Visi dan misi tersebut merupakan tindak lanjut dari kebijakan pemerintah terkait pembangunan karakter bangsa. Tahap implementasi kebijakannya meliputi sosialisasi, penerapan, dan evaluasi. Implementasi kebijakan ini menunjukkan keberhasilannya dengan sebagian besar warga sekolah menjadi terbiasa mejaga kebersihan lingkungan dan memiliki komitmen menjalankan kegiatan peduli lingkungan. Nilai-nilai karakter peduli lingkungan yang ditanamkan dipandang telah sesuai dengan yang dicanangkan oleh Kementerian Pendidikan Nasional, juga dengan apa yang
\end{abstract}


diinginkan dalam Islam yang tersirat dalam firman Allah SWT antara lain pada surat ArRuum ayat 41 dan surat Al-Qashash ayat 77.

Kata kunci: karakter peduli lingkungan, kebijakan, implementasi.

Farida, L. N., \& Karwadi. (2019). Implementasi Kebijakan Pembentukan Karakter Peduli Lingkungan. Tadbir Muwahhid, 3(1), 27-39.

\section{PENDAHULUAN}

Pemerintah Republik Indonesia menyatakan dalam Kebijakan Nasional Pembangunan Budaya dan Karakter Bangsa (2010), bahwa karakter bangsa yang telah diupayakan untuk dibangun oleh pemerintah dengan banyak cara, sampai dengan sekarang ini masih belum juga menunjukkan hasil seperti yang dicanangkan dalam tujuan yang telah direncanakan. Keadaan tersebut ditunjukkan dari kesenjangan dalam bidang sosial kemudian juga bidang ekonomi dan politik yang terhitung masih besar. Terlihat juga masih banyak sekali kerusakan lingkungan alam yang terjadi pada berbagai tempat. Penyimpangan perilaku yang memungkinkan dapat menurunkan kualitas lingkungan, dipandang sebagai bentuk perilaku ketidakpedulian terhadap lingkungan. Situasi ini bisa mengakibatkan timbulnya krisis karakter terutama karakter peduli lingkungan.

Terkait hal tersebut, Karmanto, dkk. (tanpa tahun), menyebutkan bahwa masalah yang berkaitan langsung dengan lingkungan hidup merupakan masalah semua warga negara, baik pemerintah, masyarakat, guru, dan terutama siswa. Dikarenakan siswa dididik guna menjadi generasi penerus bangsa, maka perlu diciptakan kesadaran sejak dini akan pentingnya lingkungan hidup. Lebih lanjut, Daryanto dan Suprihatin dalam Karmanto, dkk. (tanpa tahun) menyatakan, jalur pendidikan merupakan wadah yang tepat membangun penerus generasi bangsa dengan menanamkan prinsip keberlanjutan serta etika lingkungan. Sehingga dengan adanya suatu pendidikan terkait lingkungan hidup merupakan bentuk dari pengembangan warga Negara agar memiliki pengetahuan dan menumbuhkan rasa peduli terhadap lingkungan.

Wahyu Surakusumah (tanpa tahun), menyatakan bahwa realitas pada anak-anak dewasa ini cenderung mempunyai kesempatan yang begitu terbatas bercengkerama langsung dengan lingkungan hidup. Perilaku tersebut dapat menimbulkan pengaruh negatif, yang mana seharusnya memiliki kesadaran untuk selalu memandang lingkungan hidup sebagai suatu hal yang diutamakan untuk dipelihara dan dipertahankan keberadaannya. Sehingga sikap dan perilaku yang peduli terhadap lingkungan hidup dipandang penting untuk dibentuk menjadi sebuah karakter pada diri setiap individu. Hal tersebut membutuhkan sebuah kebijakan dari pemerintah maupun dari sekolah sebagai lembaga yang menyelenggarakan pendidikan. Kebijakan ini merupakan langkah strategis sebagai bentuk upaya untuk mewujudkan tercapainya tujuan yang diinginkan, yaitu terbentuknya karakter peduli lingkungan.

Pemerintah melalui Kementerian Pendidikan Nasional (2010), menyusun desain induk pendidikan karakter yang menjadi kerangka paradigmatik implementasi pembangunan karakter bangsa melalui sistem pendidikan. Salah satu nilai yang ingin dibentuk sebagai 
karakter adalah peduli lingkungan. Menanggapi kebijakan pemerintah terkait pembangunan karakter tersebut, SMP N 1 Ngemplak Sleman Yogyakarta yang beralamatkan di Jangkang, Kelurahan Widodo Martani, Kecamatan Ngemplak, Kabupaten Sleman, Provinsi Daerah Istimewa Yogyakarta, menjadikan peduli lingkungan sebagai salah satu visi sekolah.

Berdasarkan hasil wawancara dengan pihak sekolah (2017), bahwa proses berlangsungnya pembelajaran yang kondusif tidak terlepas dari kondisi lingkungan yang bersih dan asri sehingga seluruh warga sekolah merasa nyaman dan betah ketika di lingkungan sekolah. Dengan membudayakan peduli lingkungan pada seluruh komponen warga sekolah diharapkan akan terbentuk karakter peduli lingkungan pada setiap siswa secara khusus dan semua komponen sekolah pada umumnya. Sehingga penelitian ini memiliki tujuan mengetahui dan mendeskripsikan kebijakan sekaligus implementasi dan keberhasilan pembentukan karakter peduli lingkungan di SMP N 1 Ngemplak Sleman Yogyakarta.

\section{METODE}

\section{Jenis Penelitian}

Jenis penelitian ini adalah penelitian kualitatif dengan metode deskriptif analisis. Alasan pemilihan metode tersebut adalah karena penelitian ini memiliki tujuan mendeskripsikan dan menganalisis suatu gejala dan peristiwa yang terjadi, yaitu implementasi kebijakan pembentukan karakter peduli lingkungan di SMP N 1 Ngemplak Sleman Yogyakarta.

\section{Waktu dan Tempat Penelitian}

Pelaksanan penelitian ini berada di SMP N 1 Ngemplak Sleman Yogyakarta tahun ajaran 2017/2018 pada tanggal 29 Januari - 28 Februari 2018. Jangka waktu penelitian yang berlangsung selama satu bulan dipergunakan untuk memperoleh data antara lain berupa dokumen kebijakan, potret nyata kegiatan yang dilaksanakan terkait peduli lingkungan, juga pengamatan pada kondisi fisik sekolah.

\section{Subjek Penelitian}

Subjek dalam penelitian adalah pihak-pihak terkait sebagai informan meliputi kepala sekolah, wakil kepala sekolah, koordinator program Adiwiyata, ketua panitia program Adiwiyata, sekretaris panitia program Adiwiyata, guru bimbingan konseling, guru mata pelajaran Pendidikan Agama Islam (PAI), guru mata pelajaran ilmu pengetahuan alam (IPA), komite sekolah dan siswa. Pihak-pihak tersebut dipilih sebagai informan dengan pertimbangan dan tujuan tertentu (purposive) (Sukmadinata, 2010). Bahwa pihak-pihak tersebut dipandang tahu dan memungkinkan memberi informasi terkait implementasi kebijakan pembentukan karakter peduli lingkungan yang dilaksanakan di sekolah tersebut.

\section{Teknik Pengumpulan Data}

Pengumpulan data menggunakan teknik dokumentasi, wawancara mendalam, dan observasi. Wawancara mendalam dilakukan untuk mengungkap tentang konsep kebijakan pembentukan karakter peduli lingkungan, awal mula, latar belakang, dan tujuan ditetapkannya kebijakan tersebut. Juga langkah-langkah, metode, kontribusi positif, faktor pendukung, faktor penghambat serta respon setelah diimplementasikannya kebijakan tersebut. 
Instrumen pengumpulan datanya menggunakan pedoman wawancara.

Adapun observasi dilakukan guna mengamati lingkungan dan keadaan fisik sekolah. Observasi ditekankan kepada mengamati fasilitas sekolah berkaitan dengan peduli lingkungan, yaitu keadaan pengaturan ruangan, tempat yang digunakan untuk pembuangan sampah, kondisi kamar mandi sekaligus wc, saluran pembuangan limbah, pekarangan, pengaturan pohon dan tanaman pelindung. Kemudian juga mengamati kegiatan Sabtu bersih yaitu kegiatan membersihkan lingkungan di area sekolah yang dilaksanakan seluruh warga sekolah, mengamati kegiatan piket kebersihan kelas, pengamatan terhadap perilaku siswa terkait apakah sampah sudah dibuang ke tempat yang telah disediakan sesuai jenis sampahnya atau belum, mengamati pemilahan sampah baik organik maupun anorganik, juga kegiatan mengubah sampah organik menjadi pupuk kompos, dan pengamatan terhadap hasil karya siswa yang tertuang dalam majalah dinding bertema pelestarian lingkungan.

Pada beberapa kesempatan peneliti ikut terlibat untuk mengkondisikan siswa ketika melakukan pemilahan sampah yang kemudian diolah untuk diubah menjadi pupuk kompos, kemudian juga mengawasi dan mengarahkan siswa ketika kegiatan Sabtu bersih agar semua siswa turut serta membersihkan dan merawat lingkungan sekolah. Selama proses observasi peneliti juga melakukan wawancara kepada siswa, guru dan petugas kebersihan sekolah yang ikut dalam kegiatan tersebut. Instrumen pengumpulan datanya adalah menggunakan lembar observasi.

Studi dokumen digunakan untuk melengkapi sekaligus memperkaya data yang sudah didapatkan dari wawancara dan observasi. Dokumen-dokumen tersebut adalah dokumen tentang profil sekolah meliputi sejarah berdiri dan perkembangan sekolah, identitas sekolah, visi, misi, dan tujuan sekolah, keadaan siswa, kegiatan ekstrakurikuler, sarana dan prasarana yang dimiliki sekolah. Selain itu juga dokumen berupa foto kegiatan dan keadaan lingkungan sekolah berkaitan dengan peduli lingkungan, struktur panitia tim pelaksana program sekolah Adiwiyata, dokumen berupa power point materi presentasi dari dinas lingkungan hidup terkait pengelolaan lingkungan dan sekolah Adiwiyata. Instrumen pengumpulan datanya menggunakan pedoman dokumentasi.

\section{Uji Keabsahan Data}

Data yang telah diperoleh harus dibuktikan pula akan keabsahan datanya. Sebab keabsahan data suatu penelitian termasuk suatu hal yang penting karena keabsahan data merupakan salah satu langkah awal kebenaran dari analisis data. Dalam penelitian ini uji keabsahan data menggunakan teknik triangulasi yaitu triangulasi sumber dan triangulasi teknik. Triangulasi adalah teknik pemeriksaan keabsahan data yang memanfaatkan sesuatu yang lain di luar data itu untuk keperluan pengecekan atau sebagai pembanding terhadap data tersebut (Moleong, 1998).

Triangulasi sumber digunakan untuk membandingkan dan mengecek derajat kepercayaan suatu informasi yang diperoleh melalui sumber data baik wawancara, observasi, maupun dokumentasi (Sugiono, 2014). Triangulasi sumber digunakan untuk membandingkan hasil yang diperoleh dari wawancara mendalam terkait implementasi kebijakan pembentukan karakter peduli lingkungan kepada informan. Hasil wawancara yang diperoleh dari kepala 
sekolah dicek dengan hasil wawancara yang diperoleh dari wakil kepala sekolah, kemudian dicek pula dengan hasil wawancara yang diperoleh dari koordinator program Adiwiyata, guru bimbingan konseling, guru mata pelajaran PAI dan IPA, komite sekolah dan siswa.

Adapun triangulasi teknik memungkinkan peneliti untuk melengkapi kekurangan informasi yang diperoleh dengan teknik tertentu dengan menggunakan teknik lain (Danim, 2002). Triangulasi teknik digunakan untuk mengecek informasi terkait implementasi kebijakan pembentukan karakter peduli lingkungan yang sudah diperoleh melalui wawancara kepada informan dengan hasil dokumentasi serta observasi yang dilakukan peneliti terkait pelaksanaan kegiatan pembentukan karakter peduli lingkungan.

Dari triangulasi teknik tersebut, data hasil penelitian yang sudah didapatkan dari tiga teknik yang berbeda, yaitu teknik wawancara, teknik observasi, dan teknik dokumentasi saling menguatkan, sehingga diperoleh keabsahan datanya. Kedua triangulasi tersebut peneliti gunakan untuk memperolah validitas data, dengan harapan akan diperoleh tingkat keabsahan yang diterima untuk kemudian dianalisis datanya sebagai hasil data yang dapat dipercaya (credible).

\section{Teknik Analisis Data}

Data hasil penelitian berupa data hasil dokumentasi, kemudian hasil wawancara dengan informan, dan hasil observasi yang sudah diuji keabsahan datanya kemudian dianalisis untuk menjawab rumusan masalah. Analisis data dilakukan pada saat pengumpulan data berlangsung dan setelah pengumpulan data. Analisis data menggunakan analisis data Miles \& Huberman dengan aktivitas reduksi data, penyajian data, dan kesimpulan (Miles \& Huberman, 1992). Dalam aktivitas reduksi data, peneliti merangkum kemudian memilah poin-poin yang memang dibutuhkan dari wawancara yang terkait penelitian dengan informan. Selain data hasil wawancara, juga terdapat data lain yang diperoleh dari dokumentasi dan hasil observasi.

Setelah data direduksi kemudian peneliti menyajikan data tersebut berupa tabel dan narasi uraian kalimat berdasarkan hasil wawancara yang diperoleh, juga hasil dokumentasi dan hasil observasi guna mengetahui dan mendeskripsikan implementasi kebijakan pembentukan karakter peduli lingkungan di SMP N 1 Ngemplak Sleman Yogyakarta. Pada tahap penarikan kesimpulan dan verifikasi, setelah data direduksi dan kemudian disajikan, selanjutnya peneliti menarik kesimpulan dari data tersebut dengan berlandaskan pada teori terkait implementasi kebijakan pembentukan karakter peduli lingkungan.

\section{HASIL DAN PEMBAHASAN}

\section{Kebijakan Pembentukan Karakter Peduli Lingkungan}

Kebijakan pendidikan diperlukan sebagai keseluruhan proses dan hasil perumusan langkah-langkah strategis pendidikan yang dijabarkan dari visi, misi pendidikan, dalam rangka untuk mewujudkan tercapainya tujuan pendidikan dalam suatu masyarakat untuk suatu kurun waktu tertentu (Tilaar \& Nugroho, 2016). Kebijakan-kebijakan lembaga sekolah yang akan dikeluarkan menyangkut kegiatan masa depan sekolah harus selalu berpijak pada visi dan misi (Sukarno, 2002). 
SMPN 1 Ngemplak Sleman Yogyakarta telah memiliki visi, misi, dan tujuan terkait pembentukan karakter peduli lingkungan. Visi, misi, kemudian juga tujuan sekolah, dalam proses perumusannya tidak begitu saja lepas dari latar belakang yang telah berkembang sebelumnya. Berdasarkan hasil wawancara (2018) dengan Ibu Aprita Prima Hartanti, S.Pd.Si. selaku wakil kepala bidang kurikulum, bahwa gagasan kebijakan ini dimulai sejak tahun pelajaran 2016/2017 tepatnya pada bulan Juli 2016, sedangkan menurut penuturan Ibu Pipit Wijiastuti, S.Pd. selaku sekretaris panitia program Adiwiyata, gagasan kebijakan tersebut ada saat sekolah akan mengikuti lomba Adiwiyata pada tingkat Kabupaten Sleman. Namun, dari penuturan ketua panitia program Adiwiyata, Bapak Sundara, S.Pd., sebenarnya kebijakan ini sudah lama ada, yaitu sejak tahun 2005, tetapi memang semakin terasa dan dipahami gagasan tersebut ketika sekolah mengajukan diri sebagai sekolah yang membudayakan untuk peduli pada lingkungan melalui program Adiwiyata.

Adapun yang melatarbelakangi kebijakan tersebut menurut penuturan Bapak Hasim Pramono, S.Pd., selaku koordinator panitia program Adiwiyata adalah bahwa terkait lingkungan secara makro kaitannya dengan global warming, jika pengetahuan tentang global warming tidak ditanamkan kepada siswa sejak dini, maka kelak dampaknya semakin parah. Karena, walaupun telah menanamkannya pun global warming tidak turun, malah justru saat ini panas bumi semakin parah. Diharapkan dengan menanamkan peduli lingkungan kepada siswa kedepan bisa mengatasi global warming tersebut. Selanjutnya menurut penuturan Bapak Sundara, S.Pd., diakui bahwa saat ini kepedulian siswa terhadap lingkungan dirasa kurang, dan itu tanggung jawab kita semua. Lebih lanjut, menurutnya, latar belakang dilakukan kegiatan ini, tidak hanya lomba saja, tetapi sebuah ukuran keberhasilan sebuah sekolah. Tidak hanya ditunjang dari KBM saja, tetapi ditunjang oleh lingkungan yang mendukung, kalau lingkungan sejuk dan asri mungkin belajar juga menjadi lebih nyaman. Semua pihak harus mendukung dan tidak bisa lepas, artinya lingkungannya tetap harus diperhatikan. Karena rata-rata sekolah yang berprestasi memang lingkungannya juga bagus, sebab itu merupakan cerminan. Dapat dikatakan bahwa berarti manusia yang disana adalah orang-orang yang bertanggung jawab. Bisa dilihat dari lingkungannya.

Dari latar belakang tersebut selanjutnya sekolah merumuskan visi, misi, dan tujuan. Berkenaan dengan gagasan pembentukan karakter peduli lingkungan, sekolah sudah menjadikan peduli lingkungan sebagai bagian dari visi sekolah. Ditunjukkan dari sebagian kalimat visi sekolah yaitu berwawasan global dan peduli lingkungan. Sedangkan, dalam indikator visinya menyatakan bahwa sekolah menginginkan terwujudnya lulusan yang berkarakter, berbudaya, dan berwawasan lingkungan. Juga terwujudnya sarana dan prasarana pendidikan yang relevan, mutakhir, dan ramah lingkungan; terwujudnya manajemen sekolah yang mendukung pembelajaran berwawasan lingkungan hidup; serta terwujudnya lingkungan sekolah yang bersih, sehat, nyaman, rindang dan asri. (Informasi berdasarkan hasil dokumentasi, dikutip dari "Profil SMP N 1 Ngemplak", 2018).

Berangkat dari visi misi tersebut, selanjutnya sekolah merumuskan tujuan. Mengacu pada tujuan umum Pendidikan Dasar yang tercantum dalam Standar Nasional Pendidikan yaitu meletakkan dasar 
kecerdasan, akhlak mulia, pengetahuan, kepribadian serta keterampilan agar dapat hidup mandiri dan mengikuti pendidikan lanjut, maka beberapa diantara tujuan sekolah meliputi pelaksanaan kegiatan pembiasaan; mengembangkan kegiatan dalam proses pembelajaran berbasis lingkungan; meningkatkan rasa peduli dan cinta pada lingkungan; serta menjadi sekolah Adiwiyata.

Berdasarkan hasil wawancara dengan kepala sekolah, Bapak Aris Susila Pambudi, S.Pd., M.Pd., bahwa tujuan dan target yang ingin dicapai adalah pada masa yang akan datang siswa cinta terhadap lingkungan, lingkungan yang bersih dan nyaman. Semua itu tidak bisa diraih secara instan, mengingat siswa setiap tahun berganti, maka fokus sekolah adalah kepada siswa. Hal tersebut diperkuat dengan penuturan dari Ibu Aprita Prima Hartanti, S.Pd.Si., bahwa tujuan dan target yang hendak dicapai adalah ingin membentuk karakter dan pembiasaan peduli lingkungan, sehingga warga sekolah peduli lingkungan. Diharapkan siswa akan menjadi warga negara yang peduli lingkungan.

Kebijakan pembentukan karakter peduli lingkungannya mengacu kepada visi dan misi sekolah antara lain melaksanakan pendidikan karakter yang dilaksanakan dalam tiga kelompok kegiatan, yaitu pertama, pembentukan karakter yang terpadu dengan pembelajaran pada mata pelajaran. Berdasarkan hasil wawancara dengan Bapak Hasim Pramono, S.Pd. selaku guru IPA sekaligus koordinator panitia program Adiwiyata, bahwa kurikulum bernuansa peduli lingkungan diintegrasikan ke mata pelajaran. Materi yang bisa dimasuki diminta untuk menyisipkan materi peduli lingkungan, seperti mata pelajaran ilmu pengetahuan alam. Contoh, di kelas 7 terdapat materi pemanasan global dan pencemaran lingkungan. Jika dikaitkan dengan membangun karakter siswa, terkait pencemaran lingkungan, sekolah menghimbau pedagang di kantin sekolah untuk menyediakan makanan tanpa kemasan plastik, sedangkan yang sudah terlanjur ada limbah plastik digunakan untuk dibuat kerajinan plastik, pemanfaatan limbah.

Senada dengan informasi tersebut, Bapak Drs. H. Mujiana selaku guru PAI, juga menyatakan bahwa kurikulum peduli lingkungan pada pelajaran PAI antara lain pada materi hadist kebersihan. Pada kelas 7 meliputi simpati terhadap lingkungan, mandi besar, dan berwudhu terkait air. Menurutnya, nyatanya selain dipelajaran, kepedulian lingkungan juga menjadi karakter siswa pada kehidupan sehari-hari. Misal tentang kebersihan, tidak hanya kebersihan badan saja, tetapi juga kebersihan lingkungan, kebersihan kelas, kebersihan tempat tinggal, membuang sampah tidak sembarangan. Selain itu, peduli lingkungan di sekolah dibudayakan dan ditopang kurikulum Jika ada keterkaitan maka dari PAI memberikan motivasi, bahwa perbuatan seperti itu tidak hanya normatif dunia, tetapi disamping itu juga ada nilai-nilai ibadahnya. Sehingga selain melaksanakan program dari dinas, kemudian melaksanakan program di sekolah, tetapi juga dilain sisi akan memperoleh imbalan pahala dari Allah SWT, disamping itu manfaatnya juga untuk diri sendiri, dan tentu nanti di yaumul akhir akan mendapat balasan.

Kedua, pembentukan karakter yang terpadu dengan manajemen sekolah. Dalam rangka mewujudkan visi sekolah terkait pembentukan karakter peduli lingkungan, sekolah membentuk panitia program Adiwiyata. Panitia program Adiwiyata dikoordinatori oleh Bapak Hasim Pramono, 
S.Pd. dan sebagai ketua panitia program Adiwiyata adalah Bapak Sundara, S.Pd. Dalam susunan panitia tersebut tertera pembagian kader sekaligus tugas yang harus dijalankan dalam rangka mensukseskan program Adiwiyata, meliput kader anti narkoba, napza, miras dan rokok; kader bank sampah dan pembuatan kompos; kader publikasi ilmiah, pendidikan dan seni budaya; kader kesehatan dan gizi remaja; kader pembuatan kerajinan tangan, kader pemantauan jentik nyamuk, kebersihan kamar mandi dan UKS; kader kantin sehat; kader toga, green house, sayur dan buah-buahan; kader biopori, sanitasi, keindahan taman, halaman, dan tanaman dalam pot. (Informasi berdasarkan hasil dokumentasi, dikutip dari "Profil SMP N 1 Ngemplak", 2018.

Ketiga, pembentukan karakter yang terpadu dengan ekstrakurikuler, karakter yang dibentukkan diantaranya toleransi, religius, jujur, disiplin, mandiri, kerja keras, kreatif, gemar membaca, demokratis, rasa ingin tahu, cinta tanah air, tanggung jawab, peduli lingkungan. Pedoman pelaksanaan ekstrakurikuler di sekolah tersebut mengacu pada Peraturan Menteri Pendidikan dan Kebudayaan Nomor 62 Tahun 2014 tentang ekstrakurikuler, serta Peraturan Menteri Pendidikan dan Kebudayaan Nomor 63 Tahun 2014 tentang kepramukaan. Kegiatan ekstrakurikuler yang dikembangkan bersifat wajib dan pilihan. Kegiatan ekstrakurikuler wajib adalah kepramukaan, sedangkan ekstrakurikuler pilihan meliputi mading, membatik, MTQ, karawitan, tari, drum band, bola voli, futsal, pencak silat, olimpiade MIPA dan IPS, serta bahasa Inggris. Selanjutnya ekstrakurikuler pilihan yang dapat dipilih siswa maksimal 2 kegiatan. (Informasi berdasarkan hasil dokumentasi, dikutip dari "Profil SMP N 1 Ngemplak", 2018).

Selain itu, bahwa prinsip dasar program Adiwiyata, program untuk mewujudkan sekolah yang peduli dan berbudaya lingkungan (Menteri Lingkungan Hidup, 2013), yang dilaksanakan mengacu pada Peraturan Menteri Lingkungan Hidup Nomor 05 Tahun 2013. (Informasi berdasarkan hasil dokumentasi, dikutip dari power point yang dipresentasikan Dinas Lingkungan Hidup pada workshop “Pengelolaan Lingkungan", 2018).

Sekolah juga bekerjasama dengan Dinas Lingkungan Hidup, bentuk kerjasamanya dengan mengadakan kegiatan berupa pemberian workshop kepada guru dan siswa mengenai pengelolaan lingkungan sebagai pengetahuan tambahan untuk persiapan menghadapi lomba Adiwiyata pada tingkat provinsi di tahun 2018. (Informasi dari data observasi, 2018).

Program pembentukan karakter terkait peduli lingkungan yang dikutip dari hasil dokumentasi pada profil SMPN 1 Ngemplak berupa kegiatan sebagai berikut: 1) membersihkan sarana dan juga prasarana sekolah yang meliputi ruang kelas, laboratorium (IPA, bahasa, dan komputer), perpustakaan, sanitasi, lapangan upacara/ olahraga, mushola, ruang aula, ruang batik, ruang BK, ruang gamelan, ruang guru, ruang kepala sekolah, ruang OSIS, ruang TU, ruang UKS, serta area parkir. 2) Sebelum mulai KBM, seluruh siswa dan warga sekolah melakukan gerakan kebersihan lingkungan. 3) Pembiasaan melakukan bersih-bersih lingkungan sekolah dengan cara membentuk kelompok dari lintas kelas atau kader kegiatan. 4) Kegiatan Sabtu bersih dan sehat, dilakukan bergantian antara bersih-bersih lingkungan dan SKJ. 5) Peserta didik melaksanakan piket kebersihan secara beregu dan bergantian regu. 
Selanjutnya, 6) Memanfaatkan limbah air wudhu untuk pengairan kolam ikan. 7) Menanam pohon untuk penghijauan. 8) Membuang sekaligus memilah sampah sesuai jenis sampah, yaitu sampah kering dan sampah basah. 9) Melaksanakan pemilahan sampah dengan baik. 10) Mengubah sampah organik menjadi pupuk. 11) Menjual sampah kertas dan plastik di bank sampah sekolah. 12) Membuat majalah dinding yang bertema pelestarian lingkungan.

Alasan pemilihan program-program tersebut menurut penuturan Bapak Hasim Pramono, S.Pd. adalah menyesuaikan visi maupun misi di sekolah terkait peduli lingkungan. Adapun proses penentuan program tersebut meliputi, pertama, masukan dari stakeholders sekolah yang terdiri dari guru, orang tua/ wali siswa, masyarakat, dan komite sekolah. Kedua, analisis masukan tersebut oleh kepala sekolah dan staf pimpinan. Ketiga, dilakukan rapat koordinasi terkait implementasi dari visi misi. Keempat, persetujuan penetapan program sebagai kegiatan peduli lingkungan.

Dengan demikian, bahwa program sekolah yang dijalankan mengacu kepada kebijakan yang ditetapkan di sekolah dan pada dasarnya merupakan upaya untuk mewujudkan visi, misi, tujuan sekolah terkait pembentukan karakter peduli lingkungan yang telah dicanangkan.

Kebijakan sekolah tersebut senada dengan nilai-nilai pendidikan budaya dan karakter bangsa yang dicanangkan oleh Kementerian Pendidikan Nasional dalam pedoman sekolah pengembangan pendidikan budaya dan karakter bangsa (2011) yaitu sikap dan tindakan yang selalu berupaya mencegah kerusakan lingkungan alam di sekitarnya dan mengembangkan upaya-upaya untuk memperbaiki kerusakan alam yang sudah terjadi.

Islam pun mengajarkan demikian, sebagaimana dalam firman Allah SWT Quran Surat Ar-Rum ayat 41:

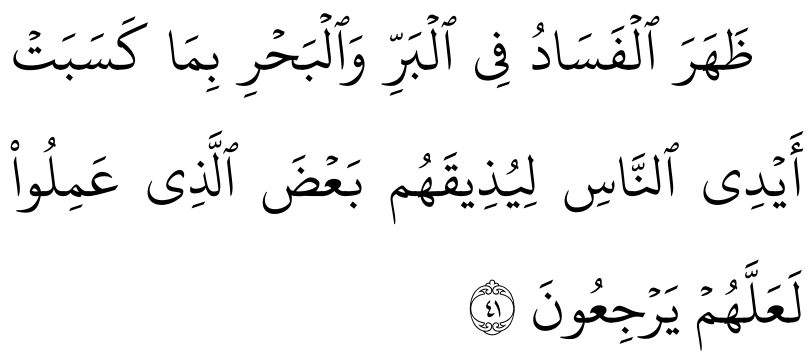

Dari surat Ar-Ruum ayat 41 tersebut (AlQuran Al-Karim, 1971) ditunjukkan bahwa terjadinya kerusakan pada alam kita yang semakin marak dewasa ini, terlihat dari gejala yang tampak berupa ketidakstabilan musim, cuaca yang sering berubah tidak menentu, sebenarnya adalah karena perbuatan manusia sendiri. Ketidakpedulian manusia terhadap lingkungannya merupakan sebab utama dari akibat yang ditimbulkan, dan tanpa disadari akibat tersebut akan dirasakan manusia pula. Melalui firman Allah SWT tersebut, merupakan petunjuk bagi manusia, bahwa kita diingatkan agar selalu menjaga kelestarian lingkungan hidup serta alam yang ada supaya terjaga karena manfaatnya akan dirasakan bagi kepentingan manusia itu sendiri.

Dalam firman lain,

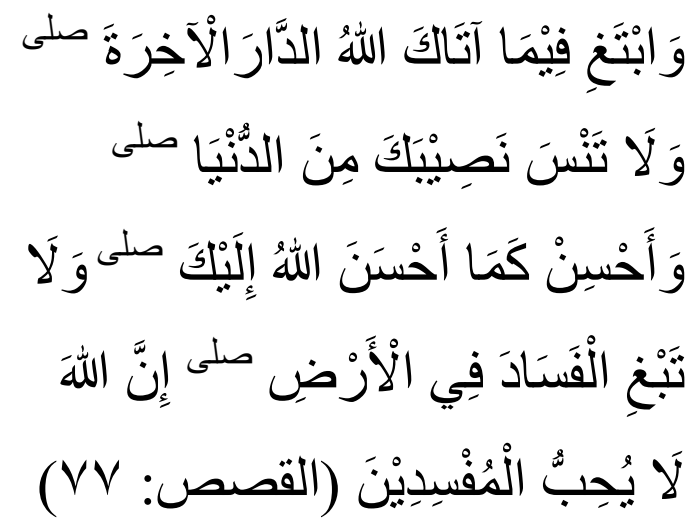

Pada surat Al-Qashash ayat 77 tersebut (Al-Quran Al-Karim, 1971) juga ditunjukkan 
bahwa Allah SWT tidak suka dengan perilaku manusia yang dengan disengaja dapat memunculkan kerusakan, sehingga tidak diperkenankan untuk melakukan tindakan yang merusak, khususnya merusak lingkungan.

\section{Tahap Implementasi Kebijakan Pembentukan Karakter Peduli Lingkungan}

Implementasi kebijakan pada prinsipnya adalah cara agar sebuah kebijakan dapat mencapai tujuannya (Nugroho, 2012). Mengacu Peraturan Menteri Pendayagunaan Aparatur Negara Nomor: PER/04/MPAN/4/2007, berikut tahap implementasi kebijakan pembentukan karakter peduli lingkungan di SMP N 1 Ngemplak Sleman Yogyakarta.

Pertama, sosialisasi kebijakan. Bapak Aris Susila Pambudi, S.Pd., M.Pd. selaku Kepala Sekolah, menuturkan bahwa sosialisasi kebijakan tersebut disampaikan kepada siswa melalui wali kelas. Dari pihak sekolah, terlebih dahulu guru diberikan pengarahan, selanjutnya pembantu kepala sekolah serta staf kesiswaan sebagai koordinatornya, sedangkan wali kelas sebagai penanggung jawab di kelas masing-masing. Selain itu, menurut Ibu Aprita Prima Hartanti, S.Pd.Si., bahwa siswa dibiasakan dengan dibuatnya tata tertib peduli lingkungan, seperti hemat air dan listrik; kegiatan Sabtu bersih dan sehat selama satu (1) jam pelajaran (JP); serta pembiasaan minimal 5 menit setiap hari untuk membersihkan sampah. Pada intinya, sekolah telah melakukan sosialisasi kebijakan sebagai langkah awal dalam implementasi kebijakan.

Kedua, penerapan kebijakan.

Berdasarkan kebijakan yang sudah dirancang, ditetapkan dan kemudian disosialisasikan, selanjutnya sekolah menerapkan kebijakan tersebut agar tujuan yang diharapkan banyak pihak dapat tercapai. Agar tujuan tercapai, sekolah menyusun kegiatan pembiasaan terkait peduli lingkungan yang tertuang dalam program sekolah sebagaimana disampaikan di awal.

Upaya pihak sekolah untuk mensukseskan kebijakan tersebut berdasarkan hasil wawancara (2018) dengan Bapak Hasim Pramono, S.Pd., Bapak Drs. H. Mujiana selaku guru PAI, Ibu Galuh Anggi Triayomi, S.Psi. selaku guru bimbingan konseling adalah dengan melakukan pembiasaan di banyak kegiatan peduli lingkungan serta keteladanan baik dari guru untuk siswa maupun sesama siswa. Selanjutya sekolah juga mengadakan studi banding pada sekolah yang menerapkan peduli lingkungan, serta melakukan metode kooperatif yang berarti bahwa setiap individu yang berada di sekolah bekerja sama dalam melakukan pengawasan dan pengendalian pada keadaan sekolah demi mensukseskan kebijakan tersebut.

Ketiga, evaluasi kebijakan. Terkait evaluasi kebijakan dapat ditinjau dari respon beberapa pihak terhadap kebijakan ini. Berdasarkan hasil wawancara (2018) dengan Ibu Aprita Prima Hartanti, S.Pd.Si., Bapak Hasim Pramono, S.Pd., Bapak Sundara, S.Pd. selaku, Ibu Galuh Anggi Triayomi, S.Psi. selaku guru BK, juga wawancara dengan Bapak Drs. H. Kholisin selaku Ketua Komite, serta wawancara dengan sampel siswa kelas VII, VIII, dan IX. Secara umum respon warga sekolah terhadap kebijakan ini adalah cukup baik dan mendukung dalam pembentukan karakter. Sekolah mendapat dukungan pihak-pihak terkait, mulai dari kepala sekolah, seluruh staf dan karyawan, guru, orang tua/ wali siswa, komite sekolah, serta siswa. 


\section{Keberhasilan Implementasi Kebijakan Pembentukan Karakter Peduli Lingkungan}

Setelah pelaksanaan kebijakan tersebut diketahui memberikan kontribusi positif, juga terdapat beberapa hal yang mendukung dan ada juga penghambatnya, serta rencana pengembangan selanjutnya. Kontribusi positif yang terjadi berupa perubahan sikap pada warga sekolah. Perubahan tersebut terlihat dari upaya yang dilakukan untuk mencegah kerusakan alam pada lingkungan sekolah dan sekitarnya. Juga upaya untuk senantiasa memperbaiki kerusakan alam pada lingkungan sekolah dan sekitarnya. Selain itu, sebagian warga sekolah menjadi terbiasa menjaga kebersihan lingkungan. Hasilnya sudah dapat dirasakan keadaan yang nyaman ketika berada di lingkungan sekolah. Kontribusi positif lainnya adalah sekolah telah memperoleh predikat juara pertama pada tingkat kabupaten sebagai sekolah Adiwiyata.

Selain kontribusi positif yang mewarnai, tidak terlepas bahwa terdapat hal-hal yang mendukung dalam pelaksanaan kebijakan tersebut juga beberapa yang menjadi penghambat, tetapi hal itu justru sebagai bahan evaluasi. Sehingga pihak sekolah dapat membuat rencana pengembangan kedepan terkait pembentukan karakter peduli lingkungan.

Faktor pendukung yang ada berperan menjadi kunci dalam mensukseskan pelaksanaan kebijakan ini. Faktor pendukung tersebut berasal dari dukungan setiap individu yang ada di dalam sekolah meliputi kepala sekolah, staf dan karyawan, guru, siswa, komite sekolah, dan partisipasi dari orang tua/ wali siswa. Selain itu, dukungan berasal dari dinas terkait meliputi dinas lingkungan hidup, dinas kehutanan, dan puskesmas setempat. Dengan kerjasama dan komunikasi yang baik dari seluruh pihak tersebut, tentu menjadi modal yang cukup untuk mensukseskan cita-cita sekolah terkait pembentukan karakter peduli lingkungan.

Dalam pelaksanaan kebijakan ini tidak terpungkiri bahwa terdapat adanya faktor penghambat yang dihadapi. Berdasarkan data observasi pada perilaku siswa terkait kepedulian terhadap sampah yang diperkuat dengan hasil ketika wawancara dengan pihak sekolah, diakui bahwa masalah sampah masih menjadi faktor penghambat yang dominan. Kepedulian siswa terhadap sampah masih perlu dibina secara bertahap. Memang tidak bisa terpungkiri lagi bahwasanya guru tidak setiap saat selalu bisa memperhatikan siswa, karena selain tugas utama guru adalah melaksanakan kegiatan mengajar di kelas juga administrasi lainnya harus dipenuhi.

Sekolah sudah memiliki rencana untuk pengembangan pada ranah pembentukan karakter peduli lingkungan. Banyak kegiatan yang hendak dilakukan untuk mensukseskan program kegiatan pembentukan karakter peduli lingkungan. Antara lain, memperbanyak biopori yaitu membuat sumuran di tanah untuk resapan air, dari BLH sudah diberikan bantuan bur dan untuk menyimpan pupuk. Selain itu, yang menarik adalah bahwa sekolah menyatakan mempunyai komitmen bahwa ada lomba maupun tidak, peduli lingkungan tetap berjalan. Karena sekolah sudah menyadari manfaat dari peduli lingkungan, yaitu kenyamanan pada lingkungan sekolah yang sudah dirasakan saat ini.

Seluruh informasi tersebut berdasarkan observasi pada perilaku siswa dan dokumentasi pada dokumen "panitia menuju sekolah Adiwiyata 2018", serta diperkuat dengan hasil wawancara (2018) 
dengan Bapak Aris Susila Pambudi, S.Pd., M.Pd. selaku Kepala Sekolah, Ibu Aprita Prima Hartanti, S.Pd.Si. selaku wakil kepala bidang kurikulum, Bapak Sundara, S.Pd. selaku ketua panitia program Adiwiyata, Bapak Hasim Pramono, S.Pd. selaku koordinator panitia program Adiwiyata, Ibu Pipin Wijiastuti, S.Pd. selaku sekretaris panitia program Adiwiyata, Bapak Drs. H. Mujiana selaku guru PAI, Ibu Galuh Anggi Triayomi, S.Psi. selaku guru BK, Ibu Siti Fatimah, S.Pd. selaku guru BK, serta Bapak Drs. H. Kholisin selaku Ketua Komite.

\section{KESIMPULAN DAN IMPLIKASI}

\section{Kesimpulan}

Kebijakan pembentukan karakter peduli lingkungan di SMPN 1 Ngemplak Sleman Yogyakarta mengacu kepada visi dan misi sekolah dengan melaksanakan pendidikan karakter yang dilaksanakan dalam tiga kelompok kegiatan, yaitu pembentukan karakter yang dipadukan dengan pembelajaran, manajemen sekolah dan ekstrakurikuler. Tahap implementasi kebijakan tersebut meliputi pertama, sosialisasi kebijakan dengan memberikan pemahaman peduli lingkungan kepada semua warga sekolah. Kedua, penerapan kebijakan dengan melakukan pembiasaan di banyak kegiatan peduli lingkungan, keteladanan baik dari guru untuk siswa maupun sesama siswa, studi banding pada sekolah yang menerapkan peduli lingkungan, serta melakukan metode kooperatif yang berarti bahwa setiap individu yang berada di sekolah bekerjasama dalam mensukseskan kebijakan tersebut. Ketiga, evaluasi kebijakan dengan meninjau respon dari berbagai pihak terkait. Keberhasilan implementasi kebijakan pembentukan karakter peduli lingkungan ini ditunjukkan dengan sebagian warga sekolah menjadi terbiasa menjaga kebersihan lingkungan. Memiliki komitmen untuk tetap menjalankan kegiatan peduli lingkungan. Hasilnya sudah dapat dirasakan keadaan yang nyaman ketika berada di lingkungan sekolah, serta telah memperoleh predikat juara pertama pada tingkat kabupaten sebagai sekolah Adiwiyata. Nilai-nilai karakter peduli lingkungan yang ditanamkan dipandang telah sesuai dengan yang dicanangkan oleh Kementerian Pendidikan Nasional, juga dengan apa yang diinginkan dalam Islam yang tersirat dalam firman Allah SWT antara lain pada surat ArRuum ayat 41 dan surat Al-Qashash ayat 77.

\section{Implikasi}

Mencermati problem dalam penyelenggaraan kebijakan ini, maka peneliti memberikan catatan saran sebagai berikut: pertama, bahwa problem yang masih dihadapi adalah kesadaran siswa untuk peduli terhadap sampah. Disarankan sekolah perlu membuat aturan tertulis berisikan penghargaan dan sanksi bagi siswa terkait kepedulian terhadap sampah. Kedua, bagi guru seyogyanya dalam melaksanakan proses belajar mengajar selalu berorientasi pada siswa. Guru sebaiknya bisa lebih kreatif dalam mengaitkan pengetahuan peduli pada lingkungan saat pembelajaran berlangsung, sehingga siswa menjadi tertarik. Ketiga, pihak sekolah lebih kompak dan selalu bekerjasama dalam menjalankan visi misi agar tercipta kondisi sekolah dengan kesadaran peduli lingkungan. Keempat, kerjasama harus selalu dilakukan dengan masyarakat di luar lingkungan sekolah dan juga instansi terkait meliputi dinas lingkungan dan lembaga swadaya masyarakat. Sehingga dukungan terus 
mengalir dari masyarakat, baik diberikan secara materiil maupun moril demi kemajuan sekolah dalam memupuk kepedulian pada lingkungan.

\section{DAFTAR PUSTAKA}

Al-Qur'an Al-Karim Dan Terjemahannya Ke Dalam Bahasa Indonesia, 1971, Jakarta: Yayasan Penyelenggara Penterjemah/ Pentafsir Al-Qur'an.

Danim, S. (2002). Menjadi Peneliti Kualitatif, cet. ke-1. Bandung: CV. Pustaka Setia.

Dokumentasi. (2018). Profil SMP N 1 Ngemplak Sleman Yogyakarta.

Karmanto, E. D. M., Makmur, M., Hayat, A. (Tanpa tahun). Kebijakan Pengintegrasian Pendidikan Lingkungan Hidup pada Sekolah 'Adiwiyata' (Studi pada SMAN 1 Puncu Kecamatan Puncu Kabupaten Kediri. Jurnal Administrasi Publik (JAP), 12(3), 1981-1985.

Menteri Pendidikan Nasional. (2010). Desain Induk Pendidikan Karakter. Jakarta: Kemendiknas.

Miles, M. B. \& Huberman, AS. M. (1992). Analisis Data Kualitatif, terj. Tjetjep, R. Jakarta: UI Press.

Moleong, L. (1998). Metodologi Penelitian Kualitatif. Bandung: Remaja Rosdakarya. Nugroho, R. (2012). Public Policy, cet. ke-IV. Jakarta: Elex Media Komputindo.
Pemerintah Republik Indonesia. (2010). Kebijakan Nasional Pembangunan Karakter Bangsa. Jakarta: Kemenkokesra.

Peraturan Menteri Lingkungan Hidup Republik Indonesia Nomor 05 Tahun 2013 tentang Pedoman Pelaksanaan Program Adiwiyata.

Peraturan Menteri Negara Pendayagunaan Aparatur Negara Nomor: PER/04/MPAN/4/2007 tentang Pedoman Umum Formulasi, Implementasi, Evaluasi Kinerja dan Revisi Kebijakan Publik di Lingkungan Lembaga Pemerintah Pusat dan Daerah.

Peraturan Pemerintah Republik Indonesia Nomor 19 Tahun 2005 tentang Standar Nasional Pendidikan.

Sugiono. (2014). Metode Penelitian Manajemen. Bandung: Alfabeta.

Sukarno, E. (2002). Sistem Pengendalian Manajemen, Suatu Pendekatan Praktik. Jakarta: Gramedia Pustaka Umum.

Sukmadinata, N. (2010). Metode Penelitian Pendidikan. Bandung: Rosda.

Surakusumah, W. (Tanpa tahun). Konsep Pendidikan Lingkungan di Sekolah: Model Uji Coba Sekolah Berwawasan Lingkungan. Bandung: Jurusan Pendidikan Biologi Fakultas Pendidikan Matematika dan Ilmu Pengetahuan Alam Universitas Pendidikan Indonesia.

Tilaar, H. A. R. \& Nugroho, R. (2016). Kebijakan Pendidikan. Yogyakarta: Pustaka Pelajar. 